\title{
Simple Squamous Epithelium
}

National Cancer Institute

\section{Source}

National Cancer Institute. Simple Squamous Epithelium. NCI Thesaurus. Code C13178.

Epithelium composed of a single layer of flat cells wider than they are tall. This epithelium

is found in anatomic sites where exchange of nutrients, wastes and gases occur. 